\title{
СПЕЦИФИКА ЭТИКЕТНОЙ НОРМЫ ПИСЬМЕННОЙ РЕЧИ СТУДЕНТОВ ВУЗОВ В ОНЛАЙН ОБЩЕНИИ
}

\section{THE SPECIFICS OF THE ETIQUETTE NORM OF WRITTEN SPEECH OF UNIVERSITY STUDENTS IN ONLINE COMMUNICATION}

\section{A. Kachanova}

S. Saburova

Summary: The article deals with the features of the use of written etiquette norms of speech of the groups "student-teacher», "teacher-teacher» of the Moscow City Pedagogical University in the digital environment based on MS Teams. Methods of statistical analysis of the material were used; the descriptive method was manifested in the analysis of the theoretical material on this issue. The prospects of the study outline the development of exercises for the groups under consideration, aimed at developing literacy in the use of etiquette norms and formulas in digital communication.

Keywords: online learning, digital environment, etiquette formulas, ethical norms of speech.

\author{
Качанова Анна Алексеевна \\ к.филол.н., дочент, Московский городской \\ педагогический университет \\ AnjaLioutaja@yandex.ru \\ Сабурова Светлана Викентьевна \\ к.п.н., доцент, Московский городской \\ педагогический университет \\ Svetlana.saburova@rambler.ru
}

Аннотация: В статье речь идет об особенностях использования письменных этикетных норм речи групп «студент-преподаватель», «преподавательпреподаватель» Московского городского педагогического университета в цифровой среде на базе платформы MS Teams. Использовались методы статистического анализа материала; описательный метод проявился в анализе теоретического материала по данному вопросу. Перспективы исследования намечают разработку упражнений для рассматриваемых групп, направленных на развитие грамотности в использовании этикетных норм и формул в цифровом общении.

Ключевые слова: онлайн-обучение, цифровая среда, этикетные формулы, этические нормы речи.

частности, по этикету в цифровой среде с целью улучшения качества онлайн общения. Актуальным остается вопрос овладения нормами сетевого этикета студентами МГПУ, правилами поведения в цифровой среде.

Не вызывает сомнения тот факт, что приветствие и обращение задают тон всему разговору. На этом этапе выбирается «ты-общение» или «Вы-общение» и соответственно приветствия (Здравствуй! или Здравствуйте! и т.п.). В нашей выборке закономерно обнаружены «Выформы» общения согласно социальной роли собеседников (группы «студент-преподаватель», «преподавательпреподаватель»). Приведем пример переписки студента с преподавателем в чате:

MS Teams (чат) 16.12.2020, 22:42 Здравствуйте! Peферат прикрепила.

MS Teams (4am) 17.12.2020, 10:05 Cnacuбo.

MS Teams (чаm) 17.12.2020, 10:27 Мария, какая у Вас специальность?

MS Teams (чат) 17.12.2020, 11:12 Пед. английский

MS Teams (чат) 17.12.2020, 11:49 Cпасибо.

«Вы-формы», входящие в парадигму русских этикетных форм вежливости, играют важнейшую роль в речевом этикете. Они подчеркивают существующую между собеседниками дистанцию и неравенство.

Преподаватели вуза выбирают должное «Вы- 
общение» согласно статусу и ситуации.

MS Teams (эл.письмо) 21.06.2021, 13:18 Добрый день, Ирина Витальевна, прикрепляю выписку. Когда я могу подписать у Вас этот документ? С уважением, Качанова A.A.

MS Teams (эл.письмо) 21.06.2021, 14:19 Анна Алексеевна, я подписала. Петр Васильевич отсканирует и вышлет Вам. С уважением, Ирина Витальевна.

«Быть вежливым и стремиться не обидеть, не задеть словом партнера по общению - это то, чему учится человек через этикетные формулы. И в этом отношении речевой этикет обладает большими возможностями в плане воспитания культуры общения в целом, потому что нормы речевого этикета предписывают выбирать речевые средства в зависимости от особенностей ситуации общения» [2].

Следующим этапом общения в цифровой среде является знакомство-представление, которое имеет свои особенности. Представиться студенту преподавателю - назвать свою фамилию, имя и отчество; курс, отделение и иную подробную информацию в целях идентификации преподавателем личности участника переписки. Например:

MS Teams (чат), 22.05,2021 13.14 Добрый день, Анна Алексеевна, я - студент 2 курса дневного отделения Казанцев Дмитрий Николаевич, недавно перевелся на обучение. Мне необходимо сдать разницу. Когда можно сдать Вам латинский язык?

MS Teams (чат) 08.12.2020, 19:56 Добрый вечер! Вас беспокоит Иванова Мария группа 207 ПОБАНГ. Домашнюю работу №5 сдала.

Рассмотрим пример, в котором отсутствует подобная информация, что затрудняет процесс общения между преподавателем и студентом (в нашей выборке зафиксировано четыре подобных случая):

MS Teams (4am), 13.05.2021, 11:22 Добрый день, Анна Алексеевна, когда я могу сдать Вам зачет по элективам? В деканате сказали, что надо договариваться с преподавателем.

Частотным оказывается выражение просьбы в извинении в письменном общении и в таком случае этикетные нормы обязывают участников коммуникации употреблять прямую, буквальную форму (Извини(те), Прости(те)) как это отражено в следующем примере:

MS Teams (чат) 25.03.2021, 21:35 Здравствуйте! Извините, что так поздно пишу, но только сейчас увидел собрание в команде. Сразу извиняюсь, что не смог прийти, мне не приходили уведомления в тимзе. Я сдал задание в тимзе, но не присутствовал на собрании 23 числа. Как я понимаю, это был перезачёт. Могу ли я как-то попасть на него в другой день? Или же попасть на следующий?
Рассмотрим следующий пример:

MS Teams (эл.почта), 18.05.2021, 22.40 Анна Алексеевна! Извините за позднее письмо. Хочу напомнить, что завтра у Вас занятия в Tеams.

В данном примере преподаватель извиняется перед коллегой за позднее письмо, которое необходимо было направить с важным напоминанием о предстоящей лекции в новом для преподавателя дистантном формате. Этикетная норма речевого и письменного поведения в реальной жизни не допускает рабочего общения после 21:00 часа, в цифровом пространстве временные рамки отсутствуют (нами зафиксировано шесть подобных примеров). Эта особенность объясняется тем фактором, что прочтение электронного письма может быть отложено получателем до удобного момента. Поэтому «потоки» электронной информации могут «сыпаться» участнику общения в любое время суток:

MS Teams (эл. письмо), 17.04.2021 22.32 Здравствуйте, дорогие коллеги! Высылаю программу конференции «Современное филологическое образование: проблемы и перспективы».

MS Teams (эл. письмо) 03.02.2021, 23:49 здравствуйте! По какой-то причине Ваши пары (Основы культуры речи) оказались в моей команде по Истории зарубежной литературы (РЛ-1813). Видимо, произошла какая-то ошибка.

MS Teams (чаm), 28.05.2021 23.56 Анна Алексеевна, я уже на финишной прямой. К утру доделаю ВКР и отправлю Вам на почту.

В первом и втором примере смягчающим фактором позднего письма является статус участника коммуникации (группа «преподаватель-преподаватель»), важность информационного сообщения и необязательность реакции на данное сообщение в тот же момент и даже на следующий день. В третьем примере студент, который пишет завершение своей выпускной квалификационной работы, желает видеть реакцию преподавателя-научного руководителя на данное сообщение, игнорируя этикетные нормы поведения письменной речи: письмо направлено в позднее время суток, а словосочетание «на финишной прямой» относится к разговорному стилю: «Выходить/выйти на финишную прямую» Разг. Начинать завершающий этап работы, подходить к завершению работы, какого л. дела [1]. Студентам необходимо придерживаться правил учтивости и корректности письменной речи с преподавателем в чатах и электронной переписке на платформе MS Teams, правил, которые характеризуются дистанцией между коммуникантами и используется при официальных отношениях.

Стоит отметить, что при выражении просьбы в речевом этикете принято представлять свои интересы в непрямом высказывании, смягчая выражение своей заинтересованности и оставляя за адресатом право выбора поступка (Не мог бы ты сейчас..., Вы не могли бы 
сказать...). Рассмотрим пример нарушения данной этикетной нормы в группе «студент-преподаватель»:

MS Teams (эл. письмо) 16.01.2020, 16:46 Здравствуйте! Мария Юдакова из 207 группы. Скажите, пожалуйста, мою оченку по культуре речи, просто сказали, что зачёт, а недавно узнала, что у нас по вашему предмету оценка.

В данном случае прямую просьбу «Скажите, пожалуйста» по нашему мнению стоит заменить косвенной, непрямой «Не могли бы Вы мне сказать мою оценку...».

Этапом общения в цифровой среде может стать переспрос какой-либо информации. Приведем пример, в котором студент уточняет информацию у преподавателя, чтобы убрать недопонимание. Правила русского речевого поведения рекомендуют использовать следующие формулы: Не могли бы Вы напомнить/повторить..., Правильно ли я понимаю... и др. В данном примере вопрос (Правильно ли я понимаю, что есть возможность сделать это сейчас у Вас?) содержит конструктивно-настраивающую формулу (Правильно ли я понимаю...).

MS Teams (чат) 23.12.2020, 15:40 здравствуйте! Вас беспокоит студентка 3 курса АКРИ-182. Мне сообщили в учебном отделе, что у меня есть академическая задолженность за 1 курс по предмету «Мышление и письмо». Проблема в том, что я в прошлом году вернулась из академического отпуска, и данного предмета в расписании уже не оказалось. В результате я не смогла его закрыть. Правильно ли я понимаю, что есть возможность сделать это сейчас у Вас?

MS Teams (чат) 23.12.2020, 18:22 Здравствуйте, я из группы 211 пед. английский, мне необходимо сегодня уехать из города. Я не смогу быть на паре по латинскому языку сегодня и выступить с докладом. У меня случилась беда. Доклад отвечу на следующей паре в четверг. Сnaсибо за понимание! С уважением, Иванчикова Мария.

Необходимо обратить внимание на формулу речевого этикета - благодарность, которая представлена во втором примере (Спасибо за понимание!). В данном случае благодарность передает чувство признательности за содействие в группе «студент-преподаватель». Подобная речевая формула используется для этикетного завершения письменного общения между студентом и преподавателем и предваряет этикетную формулу прощания (С уважением, Иванчикова Мария).

Отметим, что «понятие «речевое общение» напрямую связано с культурой речи носителя русского языка, что определяет владение нормативной базой языка и коммуникативными качествами устной и письменной речи» [4]. Проведенный нами анализ показал, что студенты, перешедшие на масштабное онлайн-обучение в 20-х годах XXI века испытывают трудности использования норм этикета в сети, правил речевого поведения в цифровой среде. В группе «студент-преподаватель» отсутствуют этикетные формулы представления, прощания и др. Преподаватели нарушают законы цифрового этикета внутри группы участников общения «преподаватель-преподаватель» в том случае, когда ответ не требует мгновенной реакции. В то же время в переписке группы «преподавательстудент» В данном исследовании нарушений норм зафиксировано не было, что говорит о проявлении высокого уровня компетенций в использовании норм русского языка преподавателями МГПУ. Перспективой исследования должны стать практические разработки системы упражнений с целью повышения качества письменной речи студентов вузов в цифровой среде.

\section{ЛИТЕРАТУРА}

1. Большой словарь русских поговорок / Под обшей редакцией В.М. Мокиенко, Т.Г. Никитина. - М., 2007 https://dic.academic.ru/dic.nsf/proverbs/38533 (дата обращения: 31.05.2021).

2. Ипполитова Н.А., Князева 0.Ю., Савова М.Р. Русский язык и культура речи: учеб. / Под ред. Н.А. Ипполитовой М., Проспект, 2004. С. 180.

3. Качанова А.А., Сабурова С.В. Речевая культура и этикет в сетевом общении: Учебное пособие. М.; СПб.: Нестор-История, 2021. С. 62.

4. Качанова А.А., Сабурова С.В. Культура устного и письменного общения: Учебное пособие. - М.; СПб.: Нестор-История, 2021.С. 4.

( К Качанова Анна Алексеевна (AnjaLioutaja@yandex.ru), Сабурова Светлана Викентьевна (Svetlana.saburova@rambler.ru) Журнал «Современная наука: актуальные проблемы теории и практики» 